\title{
Protagonist Role of Opioidergic System on Post-Traumatic Stress Disorder and Associated Pain
}

\author{
Marjan Nikbakhtzadeh ${ }^{1}$, Fatemeh Mohtashami Borzadaran² ${ }^{2}$ Elham Zamani', and Mohammad Shabani ${ }^{2} \bowtie$ \\ ${ }^{1}$ Department of Physiology, School of Medicine, Tehran University of Medical Science, Tehran, Iran \\ ${ }^{2}$ Kerman Neuroscience Research Center, Neuropharmacology Institute, Kerman University of Medical Sciences, Kerman, Iran
}

Objective Post-traumatic stress disorder (PTSD) and chronic pain often co-occur. Studies have shown an interaction between pain and PTSD. In this narrative review, we aim to support conducting comprehensive studies by describing PTSD, pain and determining whether opioidergic system, its agonist and antagonist manipulation could positively or negatively affect PTSD symptoms and concurrent pain.

Methods Term searches was done in Google Scholar, Scopus, ScienceDirect, Web of Science and PubMed databases as well as hand searching in key resource journals from 1979-2019.

Results There are a lot of contradictions and disputes when endogenous opioidergic system and opioidergic antagonist system are studied in PTSD patients. Exogenous morphine administration in PTSD patients can decrease the symptoms of PTSD but it doesn't have a pain reduction effect to an acceptable level. Beta-endorphin as an endogenous opioid is effective in pain reduction in the moment of events but after minutes to hours, the endorphins withdrawal syndrome leads to exaggerated intrusive thoughts and flashbacks of PTSD, which exacerbate the pain. It has also been shown that naloxone, as an opioidergic antagonist, can reduce or increase the PTSD symptoms and its associated pain.

Conclusion Data suggest different roles of opioidergic system and their antagonist in pain control and mood in PTSD. However, further investigations need to be done in order to reveal the role of endogenous opioidergic system and opioidergic antagonist system as a mediator in PTSD patients suffering from acute or chronic pain.

Psychiatry Investig 2020;17(6):506-516

Key Words Post-traumatic stress disorder, Pain, Opioidergic system, Naloxone, Addiction.

\section{INTRODUCTION}

Post-traumatic stress disorder (PTSD), anxiety and depression are factors that impact our lives and daily tasks. ${ }^{1}$ Studies show that more than $70 \%$ of adults experience traumatic events may lead to PTSD. ${ }^{2}$ PTSD symptoms (including: re-experiencing, avoidance of scenes or voices and hyperarousal and hypersensitivity to noise or other stimuli) ${ }^{3}$ occur after traumatic events such as car accident, rape and rescued people from earthquake may also experience these symptoms. ${ }^{4}$ These events may be associated with injury, pain $^{5}$ and negative changes in

Received: January 13, 2020 Revised: March 19, 2020

Accepted: March 24, 2020

$\triangle$ Correspondence: Mohammad Shabani, PhD

Kerman Neuroscience Research Center, Neuropharmacology Institute, Kerman University of Medical Sciences, Ebne-Sina Avenue, Kerman, 76198-13159, Iran Tel: +98-343-226-4198, Fax: +98-343-226-4198, E-mail: shabani@kmu.ac.ir

(a) This is an Open Access article distributed under the terms of the Creative Commons Attribution Non-Commercial License (https://creativecommons.org/licenses/by$\mathrm{nc} / 4.0$ ) which permits unrestricted non-commercial use, distribution, and reproduction in any medium, provided the original work is properly cited. thinking and emotions like anxiety and intrusive memory. ${ }^{6}$

Chronic pain in the body may be along with PTSD symptoms and understanding the shared mechanisms is integral in allowing providers to better serve their patients. ${ }^{7}$ At the moment of the traumatic events, endogenous opioids release to decrease pain but after several minutes or hours from the event, flashbacks are exaggerated along with intrusive thoughts as a PTSD symptom. ${ }^{8}$ Previous studies have shown that morphine administration for curing the pain in PTSD individuals is useful for diminishing the PTSD symptoms. ${ }^{9}$ Due to morphine's negative role in fear memory consolidation, repeated morphine injection or administration of morphine 48 hours after traumatic events prevent the memory formation of stress. ${ }^{10,11}$ Morphine increases the brain-derived neurotropic factor (BDNF) mRNA in regions like locus coeruleus (LC), medial prefrontal cortex (mPFC), ventral tegmental area (VTA) and amygdala. ${ }^{12}$ As a treatment line, the anti-depressant drugs like selective serotonin reuptake inhibitors (SSRI) that inhibits the 5-hydroxytryptamine (5-HT) reuptake can activate the opioi- 
dergic system. ${ }^{13}$ Opioidergic system is affected by mu and delta opioid receptors directly by increasing opioid release and suppressing the nociception transmission. However, these events are surprisingly reversed by naloxone and naltrindole. ${ }^{14} \mathrm{Nal}-$ oxone- a mixed opioid antagonist- has an affinity for mu-opioid (MOP), delta-opioid (DOP) and kappa-opioid (KOP) receptors but it is more effective on mu and delta opioid receptors compared to kappa. It does not have an effect on nociceptin/ orphanin FQ (NOP) receptors. ${ }^{15,16}$ As a result, it is claimed that naloxone has a positive effect on the itching that is induced by opioid or as a controller of opioid addiction. In another point of view, it can be advantageous in pain and PTSD signs' relief. ${ }^{17}$ Endorphin withdrawal effects and emotional numbing will disappear after naltrexone injection in rats that have perceived the inescapable shock as a model of PTSD. ${ }^{18}$ Petrakis et al., ${ }^{14}$ have shown that naltrexone alone or in coupling with SSRI anti-depressant is a good drug for modulating PTSD symptoms. Other studies have revealed that naloxone sensitizes rats to the mechanical and cold stressor in a chronic pain model. ${ }^{19}$ In an experiment by Berna et al., ${ }^{20}$ individuals exposed to burning heat showed analgesic reactions in the presence of naloxone, while the endogenous opioid system was activated. They reported that blocking endogenous opioid signaling with naloxone did not significantly affect imageryinduced regulation of pain intensity. ${ }^{20}$ Their findings indicated that analgesia is independent from opioid modulation system.

Naloxone as an opioidergic antagonist has a reciprocal effect on pain. It can block the mu-opioid receptor and partially antagonize the stress-induced analgesia that happens through endogenous opioid system in descending pain modulating pathway. The effect of the endogenous opioidergic system and opioidergic antagonist system as a mediator in PTSD patients is not clearly revealed. In this narrative review, a brief evaluation of PTSD mutual maintenance with pain is studied. The effect of endorphins, morphine as an agonist and naloxone as an antagonist in PTSD symptoms and associated pain is also investigated. In this way, maybe a window will open for psychiatrists or researchers to investigate certain drugs or ways to cure the PTSD symptoms and associated pain.

\section{METHODS}

This narrative review was done by a full-scale searching about protagonist role of opioidergic system on PTSD and associated pain in Google Scholar, Scopus, ScienceDirect, Web of Science and PubMed databases as well as hand searching in key resource journals (1979-2019). We manually screened the obtained articles and aimed at identifying original papers and reviews with a particular focus on PTSD, pain and opioidergic system. The search terms applicable to the literature search process were: "PTSD," "pain,” "acute pain,” "chronic pain," "opioid agonist and antagonist," "opioidergic system" and "opioid receptors". Besides, we used only English original articles that found to be the most appropriate in the field of opioidergic system effect on PTSD and associated pain. Even though this article tries to discuss and reveal the hidden sides of the supporting role of opioidergic system on PTSD and associated pain. It doesn't mean that it is a full-scale review that is covering all factors that have an effect on literature topic. We only discuss the studies that have information around the protagonist role of opioidergic system on PTSD and associated pain.

\section{PTSD AND THE EFFECT OF ENDOGENOUS AND EXOGENOUS OPIOIDS}

\section{PTSD, symptoms and PTSD models}

According to DSM-IV, PTSD is an anxiety disorder that may develop whenever a person is exposed to a traumatic event such as physical invasiveness, unexpected death of loved ones, war, terroristic attacks, sexual violence, natural disasters like flood, earthquake, avalanche and car accidents or airplane crash. ${ }^{4}$ PTSD is defined by three classes of symptoms including re-experiencing (nightmare, intrusive memory or interrupted scenes from the event), avoidance (staying away from talking about trauma, avoiding social activity, being hopeless about future) and hypersensitivity (hypervigilance, acoustic startle, concentration deficiency). ${ }^{4}$ PTSD will be diagnosed if these symptoms are present for a period of one or more than one month. PTSD categorizes into three orders of acute, chronic and delayed according to the onset time. ${ }^{2}$ When the symptoms exist between 1 to 3 months, the PTSD is acute and when the symptoms exist at least three months, it will be chronic. There is at least 6 months interval between events and the initiation of PTSD in delayed onset order. ${ }^{2}$ According to the last analysis, among children and adolescence, PTSD rate is $15.9 \%{ }^{21}$

The side effects of PTSD are sleep deficiency, irritability or appearance of anger, difficulty to concentrate and exaggerated startle response. ${ }^{22}$ Depression and inability are also the PTSD symptom $\mathrm{s}^{23}$ and cytokines and neurotransmitters are implicated in PTSD symptoms appearing. The pro-inflammatory cytokines such as interleukin-1 $\beta$ (IL-1 $\beta$ ), IL-6 and tumor necrosis factor (TNF- $\alpha$ ) is increased in depression but anti-inflammatory like IL-10 is elevated in anxiety. ${ }^{24} \mathrm{BDNF}$ augmentation has an important role in beginning of PTSD and increasing the arousal responses. ${ }^{12} \mathrm{LC}$ neural activity and norepinephrine release increase in PTSD. ${ }^{25,26}$ Chronic stress may also lead to hypothalamus-pituitary adrenal (HPA) axis dysfunction that contributes to major depressive disorders. ${ }^{27,28}$ Studies indicat- 
ed that PTSD enhances the corticosterone negative feedback axis at day 28 after single-prolong stress (SPS) as a model of PTSD and decreases the corticosterone concentration. ${ }^{29}$ In stress situations, corticotropin-releasing factor (CRF) also can activate the LC for norepinephrine release. ${ }^{30,31}$ The attenuated cortisol by HPA axis negative feedback may decrease the catecholamine that leads to consolidation of the PTSD traumatic memory. ${ }^{32}$ The brain regions like amygdala, medial prefrontal cortex (mPFC) and hippocampus have shown morphological changes in SPS rats. ${ }^{33}$ Jovanovic and Norrholm, ${ }^{34}$ showed that connections between amygdala and medial prefrontal cortex were disrupted in subjects undergoing chronic social stress as a model of PTSD. Animal models of PTSD can be induced by repeated stress such as restrainer, exposure to the predator (like a cat), forced swim stress, ${ }^{35}$ inescapable or escapable electrical shocks, the odor of predator (cat or cat urine) and the long-time consecutive stress such as SPS and Chronic Acute-Prolong Stress (CAPS). ${ }^{36}$ In SPS model, the animals kept in restrainer for 2 hours and then immediately force to swim for 20 minutes. They will rest for 15 minutes and then they completely anesthetize with diethyl ether. After the animals recover from anesthetization, they will be isolated in separate cages for 7 days. ${ }^{37}$ For CAPS model, animal will face chronic cold stress ( 4 centigrade degrees, 6 hours in day for 14 days), and on day 15, they will undergo the acute stress for one hour followed by isolation (20 minute). Then they will restraint for 30 minute and force to swim (10 minute) ${ }^{38}$

\section{The effect of endogenous and exogenous opioids on PTSD}

At the start of traumatic events beta- endorphin as an endogenous opioid increases and helps the individual not to experience emotional sensation. When the trauma is finished, release of beta-endorphin decreases and withdrawal effect of beta-endorphin leads to emotional stress and other symptoms of PTSD..$^{39}$ Nuller et al., ${ }^{40}$ have shown naloxone reduced the depersonalization and de-realization symptoms of PTSD. In another situation, naloxone increased the struggling and stress responses in restrained PTSD cats. ${ }^{41}$ Because of the effects of the two endogenous factors like corticotropin-releasing factor (CRF) and dynorphin on KOP receptors, these receptors have a role in fear and stress behaviors. ${ }^{42}$ PTSD symptoms have decreased by buprenorphine/naloxone effects on KOP receptors in duration of the 24 month in PTSD patients. ${ }^{43}$ Henry et al., ${ }^{44}$ have shown that in social defeated mice, enkephalin as an endogenous opioid, has a role in stress resilience and sensitization to PTSD symptoms through DOP receptors.

In stress circumstances, LC activation leads to arousal and anxiety state ${ }^{45}$ Endogenous opioid that is released in the time of SPS can decrease the LC activity and norepinephrine re- lease. ${ }^{46}$ Therefore, both of the cortisol reduction and endogenous opioid release will synchronize in consolidating the traumatic memory. Morphine administration to SPS rats as an exogenous opioid reduces the stress-enhanced fear learning. ${ }^{11}$ Zomkowski et al., ${ }^{47}$ showed that morphine injection in forced swim test, reduced the time of immobility as a fear reaction but naloxone injection as a pretreatment reversed these results. In restraint stress, naloxone increased the firing rate of LC neurons in cats. ${ }^{41}$ Valentino and Wehby reported that naltrexone alone or in morphine dependent rats increased the locus ceorelus (LC) activity.

An animal study suggested that morphine injection before traumatic events is not effective in preventing the appearance of PTSD symptoms but morphine injection after trauma decreased the possibility of PTSD occurrence. ${ }^{49}$ Due to morphine half- life and appearance of SPS symptoms 7-14 days after SPS induction, ${ }^{50}$ it seems morphine injection 24 hours after SPS exhibits a stronger effect on reduction of SPS symptoms. ${ }^{51}$ Naloxone injection to opioid dependent rats with social defeated stress has reduced opioid withdrawal signs..$^{52}$ Pitman et al., ${ }^{53}$ have shown that when the combat soldiers watch the scenes of war after injection of naloxone, the analgesic effects did not return back to them. Continues cold water swimming induces analgesia that is reversed by high dosage of naloxone and this effect may be related to non-opioid analgesia phenomena and independent of endogenous opioid. ${ }^{54}$ It supposes that analgesia is followed by intermittent cold swim stress could be mediated by endogenous opioid system and antagonized by naltrexone. ${ }^{54}$ In rats exposed to foot shock stress for a short time (intermittent), stress induced analgesia (SIA) exerted the effects by descending modulatory pain pathway. ${ }^{55}$ But foot shock stress for a long time induced the non-opioid analgesia as another type of SIA. ${ }^{56}$ However, under these circumstances (foot-shock) the morphine administration could decrease the nociceptive response via few mu-opioid receptors and other endogenous receptors (delta and kappa), ${ }^{55}$ that is why we cannot claim that this phenomenon is mediated by non-opioid mechanisms. In predator stress or its odorant on mice, the endogenous opioid analgesia or non-opioid analgesia is involved. ${ }^{57}$

\section{PAIN AND THE EFFECT OF ENDOGENOUS OR EXOGENOUS OPIOIDS ON IT}

\section{Acute pain, chronic pain and pain models}

Pain as a stressor alarms the physical threats in format of signals that incite some responses such as arousal, autonomous system activity and avoidance behavior changes. ${ }^{58}$ Experience of previous pain, culture, age and emotional factors like plea- 
sure, sadness, horror, thrill, beliefs and attitudes can affect pain responses..$^{59}$ Based on duration, pain is categorized into two types; acute and chronic. ${ }^{60}$ Acute pain is a conservative mechanism that alarms the body from imminent important danger. ${ }^{61}$ Acute pain is a normal physiologic response to chemical, mechanical and thermal stimuli that are associated with trauma, surgery and diseases. ${ }^{62}$ It may persist for less than 1 month. ${ }^{63}$ Tissue destruction that provokes the immunologic and inflammation (monoamine, cytokine, prostanoids, and peptide) responses, ${ }^{64}$ stimulates the $\mathrm{A}$ and $\mathrm{C}$ sensory fibers and conveys the nociceptive message from somatic and visceral organ to the cortical and subcortical structures (limbic and thalamus). ${ }^{65}$ In chronic diseases like arthritis and cancer, release of inflammation factors are increased and interfere with acute pain. ${ }^{65} \mathrm{So}$, if the pain suppression responses are not present in our body, a little damage can lead to a chronic pain. ${ }^{65}$ The chronic pain is defined as a kind of pain that involves one or more regions in the body and it usually can't be localized. ${ }^{66} \mathrm{It}$ lasts for more than 3 or 6 months and it takes a lot of time and effort to cure the pain. ${ }^{67}$ Studies show that chronic pain will be back after months or years, it does not follow any biological aim and also it is associated with continuous psychic changes like social, emotional, mental and physical stress. ${ }^{67}$ This pain is characterized with weak responses to medicine and causes inability in a person's life. ${ }^{68}$ About $20 \%$ of the worldwide population suffer from chronic pain. ${ }^{69}$

There are animal models of acute and chronic pain which give us further information about pain mechanisms and possible ways to cure it. Carrageenan, complete Freund's adjuvant and formalin are substances with the potential of inducing inflammation and pain via injection in animals like rat, mouse, guinea pig, cat and mammals. ${ }^{70-72}$ These substances have a focus on food pad and vibrissae pad of rats. Carrageenan and complete Freund's adjuvant induce 5 local signs of inflammation including hypersensitivity, redness, swelling, heat, and loss of function in vibrissae pad or footpad of rats. ${ }^{73}$ Carrageenan has neurogenic and non-neurogenic (inflammatory) effects similar to formalin. ${ }^{74}$ Studies show that the carrageenan can be involved in heat-hyperalgesia and may participate in mechanical hyperalgesia. ${ }^{75}$ In heat pain stimulation, the rostral anterior cingulate cortex (rACC), the binding site for opioids, has exhibited changes in PET scan images. ${ }^{76}$ The acute inflammatory pain appears after 2 or 7 days after injection of complete Freund's adjuvant in hind paw of rats and the chronic inflammatory pain appears in 28 days by increasing the transient receptor potential vanilloid-1 (TRPV1) protein expression in dorsal root ganglion (DRG). ${ }^{77}$ Several stimuli can open TRPV1 and the ionic influx from this channel may change to the action potential and chronic pain sensation. ${ }^{78}$ Formalin activates the TRPV1 on sensory neurons which leads to cal- cium entry and action potential induction that is interpreted as formalin pain. ${ }^{78}$ It seems that the cause of acute phase is the peripheral stimuli and the chronic phase is due to the inflammatory factors that aggregate in the site of formalin injection and central sensitization that happens in dorsal root horn. ${ }^{79}$

\section{The effect of endogenous or exogenous opioids on pain}

The endogenous opioid is an index of susceptibility to pain..$^{80}$ Genetic and other factors determine that pain is a resilience or augmented process. ${ }^{81}$ The endogenous opioid system has neurons in central and peripheral nervous system that exert an analgesic effect on pain input at dorsal horn of spinal cord, facial region, osteoarthritis, gastrointestinal tract $(\mathrm{GI}) .{ }^{82-85}$ Previous studies have shown that the opioids are the medication for curing acute pain such as trauma pain, surgical pain, labor pain and chronic pain which includes cancer pain or non-cancer pain. ${ }^{86}$ The classical endogenous opioids including betaendorphin, leu-enkephalin, met-enkephalin, dynorphin and Nociceptin/Orphanin FQ (N/OFQ) act through MOR $(\mu)$, DOR $(\delta)$, KOR $(\kappa)$ and NOP opioid receptors respectively. ${ }^{87}$ In addition to those common opioids, endomorphine- 1 that is located in the brain and endomorphine- 2 that is located in dorsal horn of spinal cord and medulla have been isolated from bovine and human brain and have an affinity for mu-opioid receptor. ${ }^{88-90}$ Deficiency of endorphin in descending pain inhibitory pathway has been seen in fibromyalgia. ${ }^{85}$ Exogenous opioids such as morphine, diamorphine, methadone, codeine and fentanyl are classified into agonist substances that affect MOR. ${ }^{91}$ Pain ascending pathway (Figure 1) sends the pain information from dorsal spinal cord to amygdala, periaqueductal-gray matter (PAG) and rostro-ventromedial medulla (RVM). ${ }^{92}$ Descending pain modulatory circuit that originates from hypothalamus, amygdala, and rACC, send their projection to periaqueductal gray matter (PAG) ${ }^{93}$ Projections from PAG feed the rostro ventromedial medulla (RVM), nucleus raphe magnus and nucleus reticularis gigantocellularis. ${ }^{93} \mathrm{RVM}$ has on-cell, off-cell and serotoninergic neurons. ${ }^{94}$ On-cell's neurons discharge increases in response to superficial stimuli input at dorsal horn of spinal cord but off-cells act in an opposite manner. ${ }^{94}$ From RVM, 5-HT neurons project to dorsal horn of spinal cord and activate the enkephalin neurons of this area for suppressing the pain afferent neurons..$^{84}$ Most of RVM neurons are GABAergic and glycinergic for suppressing the pain inputs at dorsal horn of spinal cord. Serotoninergic neurons from this area have dual modulatory and facilitator effects. ${ }^{95}$ Ossipov et $\mathrm{al},{ }^{93}$ showed that opioids injection into PAG disinhibited offcells and directly inhibited on-cell firing of RVM. In another pathway, $\gamma$-amino butyric acid neurons of RVM inhibit the PAG anti-nociceptive efferent neurons. ${ }^{96}$ After morphine in- 


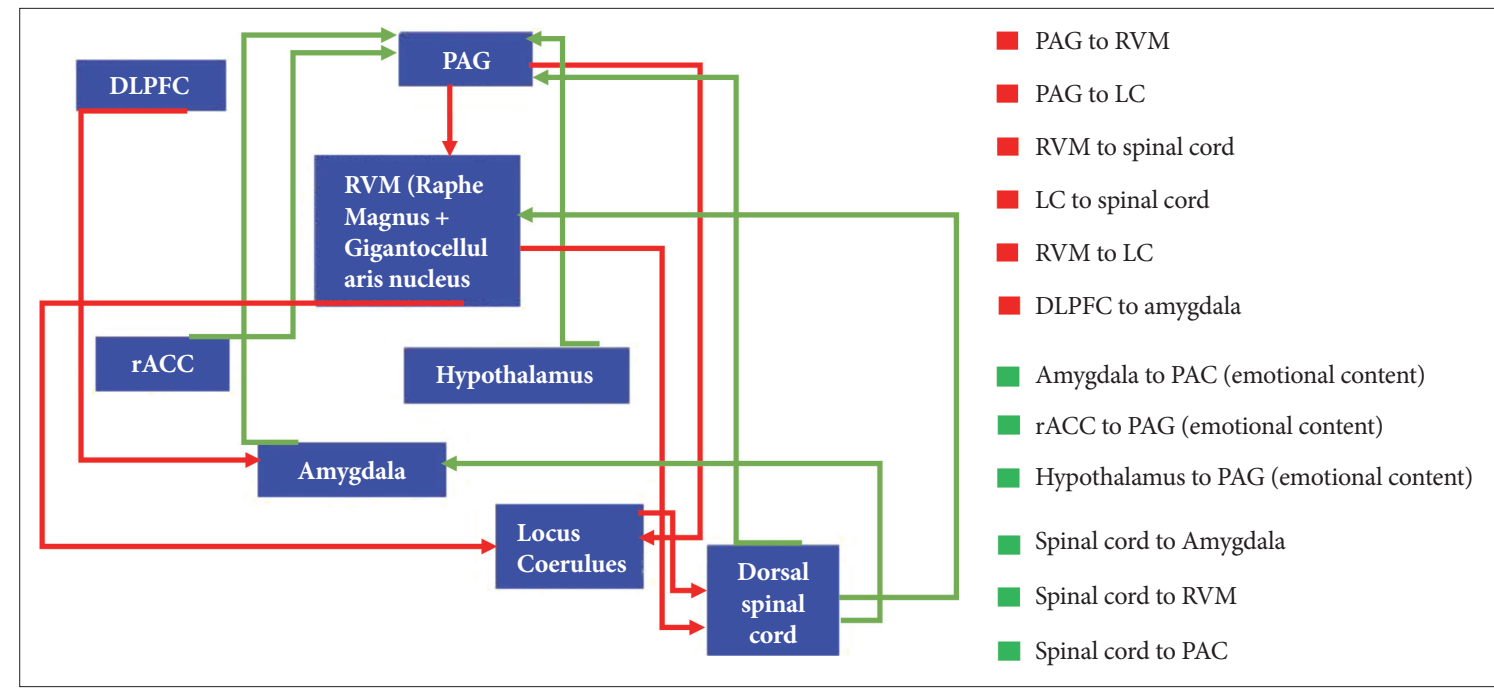

Figure 1. Schematic diagrams of ascending and descending pain pathways. Afferent neurons of nociception in ascending pain pathway transmit from spinal cord to the amygdala, rostro ventromedial medulla (RVM) and periaqueductal gray matter (PAG). The pathways that originate from amygdala, hypothalamus and rostral anterior cingulated cortex (rACC) send their projections to PAG and they are related to emotional content. Also, Locus coeruleus (LC) received the RVM projections. In reverse pathway or descending pain pathway, dorsolateral prefrontal cortex (DLPFC) neurons transmit to amygdala that helps DLPFC select reward or punishment. PAG sends the projections to RVM and LC. LC in turn projects to spinal cord for suppressing the pain message. RVM also, sends the neurons to spinal cord for inhibiting the nociceptive neuron.

jection, PAG neurons will be activated and then 5-HT neurons of RVM are excited. ${ }^{97}$ 5-HT neurons in turn activate the enkephalin neurons of dorsal horn and block the pain messages that enter via nociceptive afferent neurons. ${ }^{97}$ Morphine administration disinhibits the afferent GABA neurons to PAG via the mu opioid receptors (MOR) that exist in this area and stimulate the 5-HT neurons in the descending inhibitory pathway to the spinal cord..$^{98}$ In dorsal horn of spinal cord, CRF acts through CRF1 receptors and activates the GABA neurons and inhibit the 5-HT secretion indirectly. ${ }^{9699}$ Projection of RVM or PAG neurons to LC may exert an inhibition on presynaptic or post-synaptic neurons of dorsal spinal cord nociceptive neurons. ${ }^{94}$ The facial input also projects to RVM and then transmits to PAG via gracilis and cuneatus nuclei of medulla oblongata, and then RVM sends the inhibitory information to the trigeminal complex in the spinal cord. ${ }^{100}$ On the other hand, there is a connection between rACC and PAG and naloxone blocks mu-opioid receptors in these areas. ${ }^{101}$ In spite of naloxone antagonist properties on mu-opioid receptors and reversing the analgesic effect, in some diseases- like fibromyalgia as a kind of chronic pain- $4.5 \mathrm{mg}$ naltrexone reduced this pain by increasing the threshold of pain in subjects. ${ }^{102}$ Studies indicated that mu and delta-opioid agonist have a role in modulating the pain sensory in dorsal horn of spinal cord by inhibiting glutamate release from neurons of spinal dorsal horn. ${ }^{103}$ In heat pain and mechanical pain as an acute pain, because of the presence of the MOP and DOP receptors in afferent terminals of dorsal horn, DRG and dorsal horn, MOP and DOP agonists are useful for relieving the heat pain and mechanical pain respectively..$^{104} \mathrm{MOP}$ receptor's availability in DRG or nodose ganglia are responsible for agonist's impression in these regions. ${ }^{104}$ In chronic pain, the presence of mu-opioid receptors in central and peripheral primary afferent neurons is the cause of hyperalgesia inhibition. ${ }^{105}$ In neuropathic pain that originates from spinal cord injury, the NOP, DOP, MOP, and KOP receptor agonists decreased the hypersensitivity to the pain but naloxone $(1 \mathrm{mg} / \mathrm{kg})$ and naltrindole $(10 \mathrm{mg} / \mathrm{kg})$ increased this type of pain. ${ }^{106}$ Down regulation of mu-opioid receptors in rat spinal cord and dorsal root ganglion have been observed a few weeks after the spinal cord injury. ${ }^{107} \mathrm{PET}$ scan study also has shown the changes in delta and kappa receptors in this pain. ${ }^{108}$ The nitric oxide (NO) inhibitor could have elevated the effects of MOP, DOP and KOP receptors' agonists on the acute and chronic pain. ${ }^{109}$

The Linkage between amygdala and dorsal lateral prefrontal cortex (DLPFC), has an essential role in emotional modulation of functions for achieving a goal or avoidance from punishment. ${ }^{110}$ DLPFC has a role in cognitive function, working memory, decision making and pain. ${ }^{111}$ DLPFC and rACC are active during the first phase of pain but hypothalamus, PAG and RVM are active during first and second phases of pain. ${ }^{101}$ Repeated intrathecal morphine injection $(5 \mathrm{mg} / \mathrm{mL})$ released the pro-inflammatory cytokines like IL-1 $\beta$, IL- 6 and TNF- $\alpha$ that is aggregated in the body ${ }^{112,113}$ and contributes in hyperalgesia and allodynia. ${ }^{114}$ On the other hand, Grabow and Dougherty, ${ }^{115}$ showed that intrathecal injection of morphine before orofacial formalin test, reduced pain in both phases of formalin test in rats. They reported that naloxone $(10 \mu \mathrm{g})$ increased 
M Nikbakhtzadeh et al.

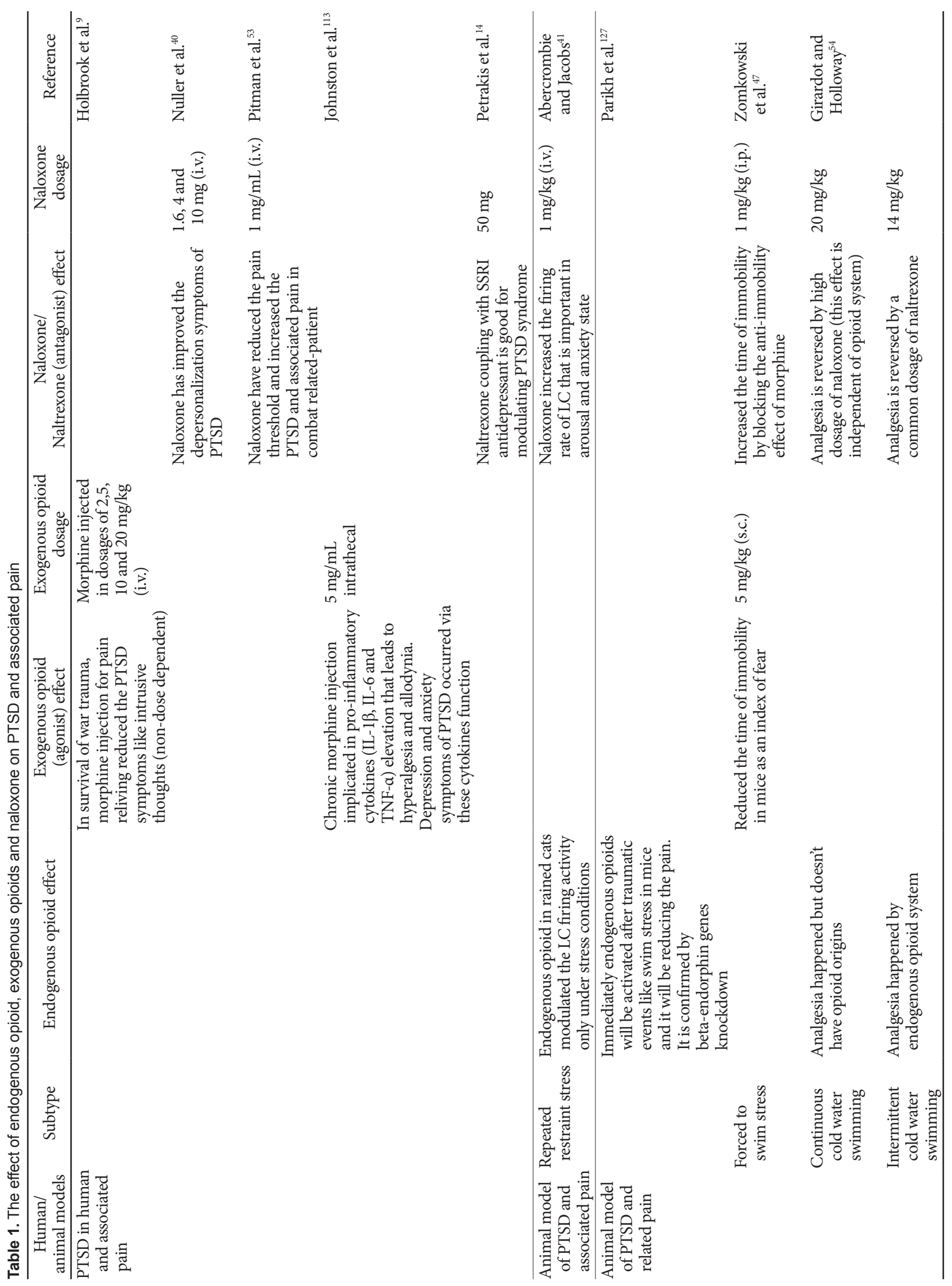




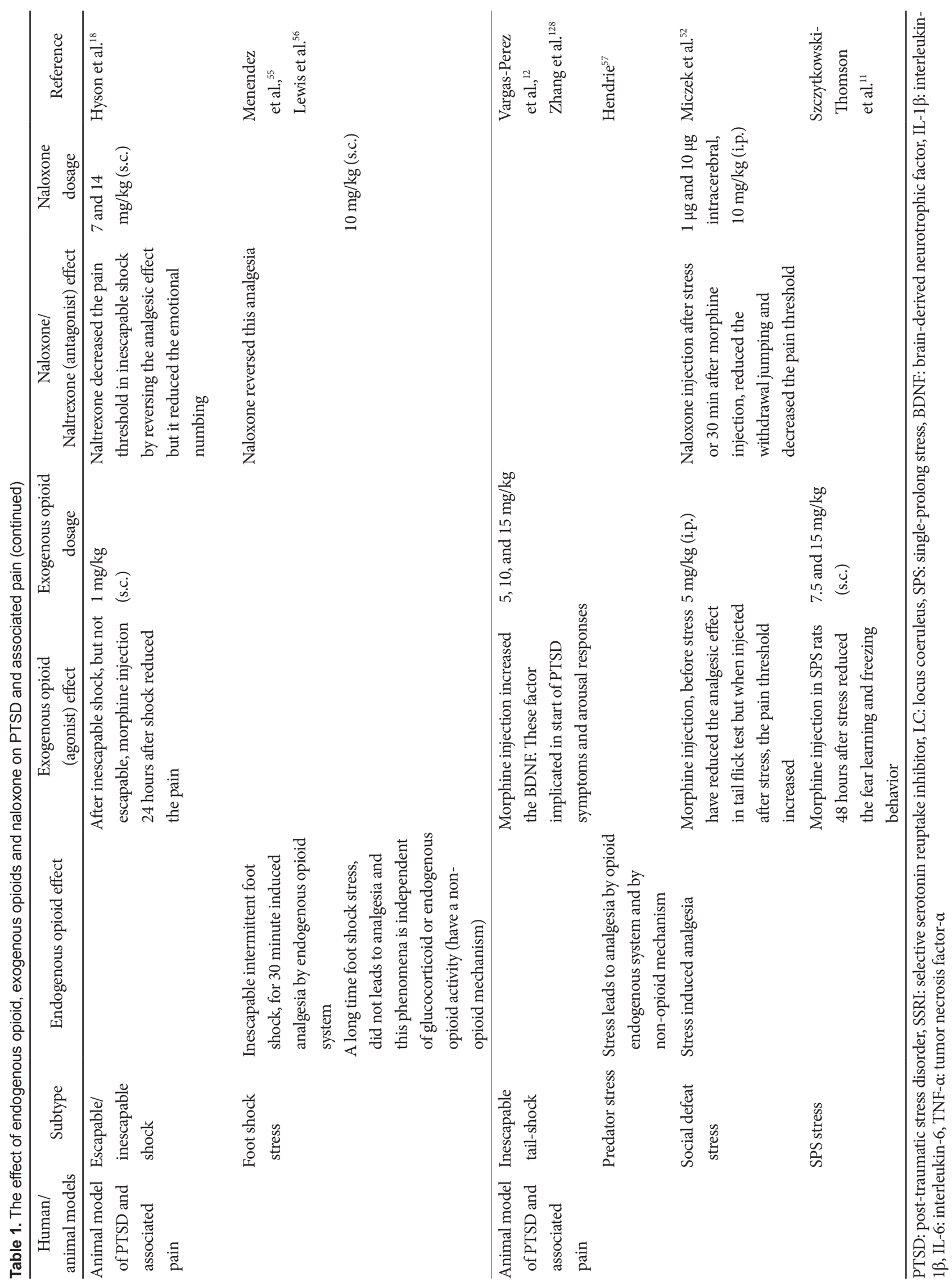

512 Psychiatry Investig 2020;17(6):506-516 
pain in phase- 1 and reduced pain in phase- 2 of formalin test. Other investigations indicated that naloxone in low dosage (picogram, s.c.) had an anti-nociceptive effect in two phases of formalin test by binding to classical opioidergic receptors. ${ }^{116}$ Naloxone reduced the mechanical threshold in allodynia test in transgenic mouse model of Alzheimer's disease. ${ }^{82}$ In Spinal cord injured rats that were bothered by pain, the endogenous opioidergic system was activated but naloxone blocked mureceptors and rats showed mechanical and cold allodynia responses. $^{117}$

However, there are a few contradictions regarding different roles of opioidergic system and their antagonist in pain control and mood in PTSD. So, further investigations need to be done in order to reveal the role of opioidergic system in PTSD patients suffering from acute or chronic pain.

\section{HOW IS THE MUTUAL MAINTENANCE RELATION BETWEEN PTSD AND PAIN?}

An important relationship exists between PTSD and pain. Increased intensity of one can lead to enhancements in the other. ${ }^{5}$ Something that connects these two problems together is depression and inability as a sign of PTSD. ${ }^{118}$ Both of them enhance the PTSD and pain. ${ }^{119}$ There is comorbidity between PTSD and chronic pain. ${ }^{120}$ Patients with chronic pain have avoidance behaviors in risky conditions. ${ }^{120}$ Following chronic swim stress, Nazeri et al., ${ }^{121}$ showed there is a relationship between thermal hyperalgesia with passive avoidance task impairments and increased locomotion. PTSD may mediate the initiation and exacerbate the headache pain such as migraine pain. ${ }^{122,123}$ The breast cancer survivals are the cases that have susceptibility for revealing the PTSD symptoms. ${ }^{124}$ PTSD is prevalent in fibromyalgia and it increases this type of pain but it doesn't occur in dyspepsia. ${ }^{125}$ An animal study showed that the acute restrained stress did not show any changes in Temporomandibular Joint (TMJ) formalin test but chronic restrainer stress increased the pain response in this region. ${ }^{126}$ Gameiro et al. ${ }^{126}$ showed that morphine injection in restrained rats prior to formalin test decreased the pain but it did not show any significant difference in pain response compared to control in the rat. It seems pain and PTSD are conditions that commonly co-occur and further research is required to find treatment protocols and more effective assessment for use when they co-occur.

\section{CONCLUSION}

PTSD increases pain, and chronic pain exacerbates the symptoms of PTSD. Beta-endorphins in stress condition including the moment of traumatic stress, in duration and end of it exag- gerate the symptoms of PTSD, and morphine as a therapeutic line can dampen PTSD symptoms in some patients. On the other hand, sometimes, morphine injection doesn't have this effect and the pain becomes worse in the PTSD while naloxone has a reverse effect and the pain and symptoms of PTSD become better. Hence, it seems both of the endogenous opioidergic and opioidergic antagonist systems are effective in pain reduction (Table 1). The role of opioidergic system in pain control and PTSD is suggested based on available data, however, data from these studies require more comprehensive studies, which are essential to empirically test whether endogenous opioidergic are involved in pain and PTSD symptoms, and to determine mechanisms of action for endogenous opioidergic in regulation of affect.

\section{Acknowledgments}

The authors are grateful to Dr. Mina Behzadi for providing practical comments on the manuscript.

\section{Conflicts of Interest}

The authors have no potential conflicts of interest to disclose.

\section{Author Contributions}

Conceptualization: Marjan Nikbakhtzadeh, Mohammad Shabani. Data curation: Marjan Nikbakhtzadeh. Formal analysis: Mohammad Shabani. Funding acquisition: Mohammad Shabani. Investigation: Marjan Nikbakhtzadeh. Methodology: Marjan Nikbakhtzadeh, Elham Zamani. Project administration: Mohammad Shabani. Resources: Fatemeh Mohtashami Borzadaran. Software: Fatemeh Mohtashami Borzadaran. Supervision: Mohammad Shabani. Validation: Marjan Nikbakhtzadeh, Mohammad Shabani. Visualization: Fatemeh Mohtashami Borzadaran, Elham Zamani. Writing-original draft: Marjan Nikbakhtzadeh, Mohammad Shabani. Writing-review \& editing: all authors.

\section{ORCID iDs}

$\begin{array}{ll}\text { Marjan Nikbakhtzadeh } & \text { https://orcid.org/0000-0003-0867-3288 } \\ \text { Fatemeh Mohtashami Borzadaran } & \\ & \text { https://orcid.org/0000-0001-9721-4248 } \\ \text { Elham Zamani } & \text { https://orcid.org/0000-0002-2988-3551 } \\ \text { Mohammad Shabani } & \text { https://orcid.org/0000-0002-2082-5849 }\end{array}$

\section{REFERENCES}

1. Wang CH, Tsay SL, Bond AE. Post-traumatic stress disorder, depression, anxiety and quality of life in patients with traffic-related injuries. J Adv Nurs 2005;52:22-30.

2. Shalev A, Liberzon I, Marmar C. Post-traumatic stress disorder. N Engl J Med 2017;376:2459-2469.

3. Adhikari Baral I, K C B. Post traumatic stress disorder and coping strategies among adult survivors of earthquake, Nepal. BMC Psychiatry 2019;19:118.

4. Spitzer RL, Williams JB. Diagnostic and statistical manual of mental disorders. Paper presented at: American Psychiatric Association; 1980.

5. Asmundson GJ, Coons MJ, Taylor S, Katz J. PTSD and the experience of pain: research and clinical implications of shared vulnerability and mutual maintenance models. Can J Psychiatry 2002;47:930937.

6. Bisson JI, Cosgrove S, Lewis C, Robert NP. Post-traumatic stress disorder. BMJ 2015;351:h6161. 
7. Poundja J, Fikretoglu D, Brunet A. The co-occurrence of posttraumatic stress disorder symptoms and pain: Is depression a mediator? J Trauma Stress 2006;19:747-751.

8. Volpicelli J, Balaraman G, Hahn J, Wallace H, Bux D. The role of uncontrollable trauma in the development of PTSD and alcohol addiction. Alcohol Res Health 1999;23:256-262.

9. Holbrook TL, Galarneau MR, Dye JL, Quinn K, Dougherty AL. Morphine use after combat injury in Iraq and post-traumatic stress disorder. N Engl J Med 2010;362:110-117.

10. Castellano C, Cestari V, Cabib S, Puglisi-Allegra S. The effects of morphine on memory consolidation in mice involve both D1 and D2 dopamine receptors. Behav Neural Biol 1994;61:156-161.

11. Szczytkowski-Thomson JL, Lebonville CL, Lysle DT. Morphine prevents the development of stress-enhanced fear learning. Pharmacol Biochem Behav 2013;103:672-677.

12. Vargas-Perez H, Bahi A, Bufalino MR, Ting-A-Kee R, Maal-Bared G, Lam J, et al. BDNF signaling in the VTA links the drug-dependent state to drug withdrawal aversions. J Neurosci 2014;34:7899-7909.

13. Duman EN, Kesim M, Kadioglu M, Yaris E, Kalyoncu NI, Erciyes N. Possible involvement of opioidergic and serotonergic mechanisms in antinociceptive effect of paroxetine in acute pain. J Pharmacol Sci 2004;94:161-165.

14. Petrakis IL, Ralevski E, Desai N, Trevisan L, Gueorguieva R, Rounsaville B, et al. Noradrenergic vs serotonergic antidepressant with or without naltrexone for veterans with PTSD and comorbid alcohol dependence. Neuropsychopharmacology 2012;37:996-1004.

15. Dietis N, Rowbotham DJ, Lambert DG. Opioid receptor subtypes: fact or artifact? Br J Anaesth 2011;107:8-18.

16. Sakoori K, Murphy NP. Central administration of nociceptin/orphanin FQ blocks the acquisition of conditioned place preference to morphine and cocaine, but not conditioned place aversion to naloxone in mice. Psychopharmacology 2004;172:129-136.

17. Adams JM. Increasing Naloxone Awareness and Use: The Role of Health Care Practitioners. JAMA 2018;319:2073-2074.

18. Hyson RL, Ashcraft LJ, Drugan RC, Grau JW, Maier SF. Extent and control of shock affects naltrexone sensitivity of stress-induced analgesia and reactivity to morphine. Pharmacol Biochem Behav 1982; 17:1019-1025.

19. Hao JX, Yu W, Xu XJ. Evidence that spinal endogenous opioidergic systems control the expression of chronic pain-related behaviors in spinally injured rats. Exp Brain Res 1998;118:259-268.

20. Berna C, Leknes S, Ahmad AH, Mhuircheartaigh RN, Goodwin GM, Tracey I. Opioid-independent and opioid-mediated modes of pain modulation. J Neurosci 2018;38:9047-9058.

21. Alisic E, Zalta AK, van Wesel F, Larsen SE, Hafstad GS, Hassanpour $\mathrm{K}$, et al. Rates of post-traumatic stress disorder in trauma-exposed children and adolescents: meta-analysis. Br J Psychiatry 2014;204: 335-340.

22. Defrin R, Ginzburg K, Solomon Z, Polad E, Bloch M, Govezensky M, et al. Quantitative testing of pain perception in subjects with PTSDimplications for the mechanism of the coexistence between PTSD and chronic pain. Pain 2008;138:450-459.

23. Roth RS, Geisser ME, Bates R. The relation of post-traumatic stress symptoms to depression and pain in patients with accident-related chronic pain. J Pain 2008;9:588-596.

24. Zou W, Feng R, Yang Y. Changes in the serum levels of inflammatory cytokines in antidepressant drug-naive patients with major depression. PLoS One 2018;13:e0197267.

25. Southwick SM, Bremner JD, Rasmusson A, Morgan CA 3rd, Arnsten A, Charney DS. Role of norepinephrine in the pathophysiology and treatment of posttraumatic stress disorder. Biol Psychiatry 1999;46: 1192-1204

26. Wong ML, Kling MA, Munson PJ, Listwak S, Licinio J, Prolo P, et al. Pronounced and sustained central hypernoradrenergic function in major depression with melancholic features: relation to hypercorti- solism and corticotropin-releasing hormone. Proc Natl Acad Sci U S A 2000;97:325-330

27. McEwen BS. The neurobiology of stress: from serendipity to clinical relevance. Brain Res 2000;886:172-189.

28. Lichtblau N, Schmidt FM, Schumann R, Kirkby KC, Himmerich H. Cytokines as biomarkers in depressive disorder: current standing and prospects. Int Rev Psychiatry 2013;25:592-603.

29. Zhang Y, Gandhi PR, Standifer KM. Increased nociceptive sensitivity and nociceptin/orphanin FQ levels in a rat model of PTSD. Mol Pain 2012;8:76.

30. Curtis AL, Grigoriadis DE, Page ME, Rivier J, Valentino RJ. Pharmacological comparison of two corticotropin-releasing factor antagonists: in vivo and in vitro studies. J Pharmacol Exp Ther 1994;268: 359-365.

31. Curtis AL, Lechner SM, Pavcovich LA, Valentino RJ. Activation of the locus coeruleus noradrenergic system by intracoerulear microinfusion of corticotropin-releasing factor: effects on discharge rate, cortical norepinephrine levels and cortical electroencephalographic activity. J Pharmacol Exp Ther 1997;281:163-172.

32. Yehuda R, McFarlane AC, Shalev AY. Predicting the development of posttraumatic stress disorder from the acute response to a traumatic event. Biol Psychiatry 1998;44:1305-1313.

33. Cui H, Sakamoto H, Higashi S, Kawata M. Effects of single-prolonged stress on neurons and their afferent inputs in the amygdala. Neuroscience 2008;152:703-712.

34. Jovanovic T, Norrholm SD. Neural mechanisms of impaired fear inhibition in posttraumatic stress disorder. Front Behav Neurosci 2011; 5:44.

35. Siegmund A, Wotjak CT. Toward an animal model of posttraumatic stress disorder. Ann N Y Acad Sci 2006;1071:324-334.

36. Hendriksen H, Prins J, Olivier B, Oosting RS. Environmental enrichment induces behavioral recovery and enhanced hippocampal cell proliferation in an antidepressant-resistant animal model for PTSD. PLoS one 2010;5:e11943.

37. Pitman RK, Rasmusson AM, Koenen KC, Shin LM, Orr SP, Gilbertson MW, et al. Biological studies of post-traumatic stress disorder. Nat Rev Neurosci 2012;13:769-787.

38. Roth MK, Bingham B, Shah A, Joshi A, Frazer A, Strong R, et al. Effects of chronic plus acute prolonged stress on measures of coping style, anxiety, and evoked HPA-axis reactivity. Neuropharmacology 2012;63:1118-1126.

39. Volpicelli J, Balaraman G, Hahn J, Wallace H, Bux D. The role of uncontrollable trauma in the development of PTSD and alcohol addiction. Alcohol Res Health 1999;23:256-262.

40. Nuller YL, Morozova MG, Kushnir ON, Hamper N. Effect of naloxone therapy on depersonalization: a pilot study. J Psychopharmacol 2001;15:93-95.

41. Abercrombie ED, Jacobs BL. Systemic naloxone administration potentiates locus coeruleus noradrenergic neuronal activity under stressful but not non-stressful conditions. Brain Res 1988;441:362-366.

42. Van't Veer A, Carlezon WA Jr. Role of kappa-opioid receptors in stress and anxiety-related behavior. Psychopharmacology (Berl) 2013;229: 435-452.

43. Lake EP, Mitchell BG, Shorter DI, Kosten T, Domingo CB, Walder AM. Buprenorphine for the treatment of posttraumatic stress disorder. Am J Addict 2019;28:86-91.

44. Henry MS, Bisht K, Vernoux N, Gendron L, Torres-Berrio A, Drolet $\mathrm{G}$, et al. Delta opioid receptor signaling promotes resilience to stress under the repeated social defeat paradigm in mice. Front $\mathrm{Mol} \mathrm{Neu-}$ rosci 2018;11:100.

45. Foote SL, Aston-Jones G, Bloom FE. Impulse activity of locus coeruleus neurons in awake rats and monkeys is a function of sensory stimulation and arousal. Proc Natl Acad Sci U S A 1980;77:3033-3037.

46. George SA, Knox D, Curtis AL, Aldridge JW, Valentino RJ, Liberzon I. Altered locus coeruleus-norepinephrine function following single 
prolonged stress. Euro J Neurosci 2013;37:901-909.

47. Zomkowski AD, Santos AR, Rodrigues AL. Evidence for the involvement of the opioid system in the agmatine antidepressant-like effect in the forced swimming test. Neurosci Lett 2005;381:279-283.

48. Valentino RJ, Wehby RG. Locus ceruleus discharge characteristics of morphine-dependent rats: effects of naltrexone. Brain Res 1989;488: 126-134.

49. Butler RK, Finn DP. Stress-induced analgesia. Prog Neurobiol 2009; 88:184-202.

50. Liberzon I, Krstov M, Young EA. Stress-restress: effects on ACTH and fast feedback. Psychoneuroendocrinology 1997;22:443-453.

51. RaiseAbdullahi P, Vafaei AA, Ghanbari A, Dadkhah M, RashidyPour A. Time-dependent protective effects of morphine against behavioral and morphological deficits in an animal model of posttraumatic stress disorder. Behav Brain Res 2019;364:19-28.

52. Miczek KA, Thompson ML, Shuster L. Analgesia following defeat in an aggressive encounter: development of tolerance and changes in opioid receptors. Ann N Y Acad Sci 1986;467:14-29.

53. Pitman RK, van der Kolk BA, Orr SP, Greenberg MS. Naloxone-reversible analgesic response to combat-related stimuli in posttraumatic stress disorder. A pilot study. Arch Gen Psychiatry 1990;47:541-544.

54. Girardot MN, Holloway FA. Intermittent cold water stress-analgesia in rats: cross-tolerance to morphine. Pharmacol Biochem Behav 1984; 20:631-633.

55. Menendez L, Andres-Trelles F, Hidalgo A, Baamonde A. Opioid footshock-induced analgesia in mice acutely falls by stress prolongation. Physiol Behav 1993;53:1115-1119.

56. Lewis JW, Cannon JT, Liebeskind JC. Opioid and nonopioid mechanisms of stress analgesia. Science 1980;208:623-625.

57. Hendrie CA. The calls of murine predators activate endogenous analgesia mechanisms in laboratory mice. Physiol Behav 1991;49:569573.

58. Ribeiro SC, Kennedy SE, Smith YR, Stohler CS, Zubieta JK. Interface of physical and emotional stress regulation through the endogenous opioid system and $\mu$-opioid receptors. Prog Neuropsychopharmacol Biol Psychiatry 2005;29:1264-1280.

59. Chaturvedi S, Chaturvedi A. Postoperative pain and its management. Medknow Publications on behalf of the Indian Society of Critical Care Medicine 2007;11:204-211.

60. Harvey AM. Classification of chronic pain-descriptions of chronic pain syndromes and definitions of pain terms. Clin J Pain 1995;11:163.

61. Classification of chronic pain. Descriptions of chronic pain syndromes and definitions of pain terms. Prepared by the International Association for the Study of Pain, Subcommittee on Taxonomy. Pain Suppl 1986;3:S1-S226.

62. West J, Aronoff G, Dahl J, Johnson S, Joranson D, Koontz W. Model Guidelines for the Use of Controlled Substances for the Treatment of Pain. Dallas, TX: A policy document of the Federation of State Medical Boards of the United States Inc; 1998.

63. Harvey AM. Classification of chronic pain-descriptions of chronic pain syndromes and definitions of pain terms. Clin J Pain 1995;11: 163.

64. Wall P. Inflammatory and neurogenic pain: new molecules, new mechanisms. Br J Anaesthes 1995;75:123-124.

65. Carr DB, Goudas LC. Acute pain. Lancet 1999;353:2051-2058

66. Treede RD, Rief W, Barke A, Aziz Q, Bennett MI, Benoliel R, et al. A classification of chronic pain for ICD-11. Pain 2015;156:1003-1007.

67. Lam DK, Sessle BJ, Cairns BE, Hu JW. Neural mechanisms of temporomandibular joint and masticatory muscle pain: a possible role for peripheral glutamate receptor mechanisms. Pain Res Manag 2005; 10:145-152.

68. Gremillion HA. Multidisciplinary diagnosis and management of orofacial pain. Gen Dent 2002;50:178-189.

69. Goldberg DS, McGee SJ. Pain as a global public health priority. BMC Public Health 2011;11:770.
70. Yuan T, Li J, Shen L, Zhang W, Wang T, Xu Y, et al. Assessment of itch and pain in animal models and human subjects. Adv Exp Med Biol 2016;904:1-22.

71. Matson DJ, Hamamoto DT, Bregman H, Cooke M, DiMauro EF, Huang L, et al. Inhibition of inactive states of tetrodotoxin-sensitive sodium channels reduces spontaneous firing of $\mathrm{C}$-fiber nociceptors and produces analgesia in formalin and complete Freund's adjuvant models of pain. PLoS one 2015;10:e0138140.

72. Gong N, Huang Q, Chen Y, Xu M, Ma S, Wang YX. Pain assessment using the rat and mouse formalin tests. Bio-protocol 2014;4:e1288.

73. McCarson KE. Models of inflammation: Carrageenan-or Complete Freund's Adjuvant (CFA)-induced edema and hypersensitivity in the rat. Curr Protoc Pharmacol 2015;70:5.4. 1-5.4.9.

74. Bölcskei K, Helyes Z, Szabó Á, Sándor K, Elekes K, Németh J, et al. Investigation of the role of TRPV1 receptors in acute and chronic nociceptive processes using gene-deficient mice. Pain 2005;117:368376.

75. Watanabe M, Ueda T, Shibata Y, Kumamoto N, Shimada S, Ugawa S. Expression and regulation of Cav3. 2 T-type calcium channels during inflammatory hyperalgesia in mouse dorsal root ganglion neurons. PLoS One 2015;10:e0127572.

76. Sprenger T, Valet M, Boecker H, Henriksen G, Spilker ME, Willoch F, et al. Opioidergic activation in the medial pain system after heat pain. Pain 2006;122:63-67.

77. Yu L, Yang F, Luo H, Liu FY, Han JS, Xing GG, et al. The role of TRPV1 in different subtypes of dorsal root ganglion neurons in rat chronic inflammatory nociception induced by complete Freund's adjuvant. Mol Pain 2008;4:61.

78. Choi SI, Lim JY, Yoo S, Kim H, Hwang SW. Emerging role of spinal cord TRPV1 in pain exacerbation. Neural Plast 2016;2016:5954890.

79. Tjølsen A, Berge OG, Hunskaar S, Rosland JH, Hole K. The formalin test: an evaluation of the method. Pain 1992;51:5-17.

80. Bodnar RJ. Endogenous opiates and behavior: 2013. Peptides 2014; 62:67-136

81. Holliday KL, Nicholl BI, Macfarlane GJ, Thomson W, Davies KA, McBeth J. Do genetic predictors of pain sensitivity associate with persistent widespread pain? Mol Pain 2009;5:56.

82. Aman Y, Pitcher T, Ballard C, Malcangio M. Impaired chronic painlike behaviour and altered opioidergic system in the TASTPM mouse model of Alzheimer's disease. Eur J Pain 2019;23:91-106.

83. Hughes PA, Costello SP, Bryant RV, Andrews JM. Opioidergic effects on enteric and sensory nerves in the lower GI tract: basic mechanisms and clinical implications. Am J Physiol Gastrointest Liver Physiol 2016;311:G501-G513.

84. Willis WD Jr. Central nervous system mechanisms for pain modulation. Appl Neurophysiol 1985;48:153-165.

85. Julien N, Goffaux P, Arsenault P, Marchand S. Widespread pain in fibromyalgia is related to a deficit of endogenous pain inhibition. Pain 2005;114:295-302.

86. Nafziger AN, Barkin RL. Opioid Therapy in Acute and Chronic Pain. J Clin Pharmacol 2018;58:1111-1122.

87. Przewlocki R, Przewlocka B. Opioids in chronic pain. Eur J Pharmacol 2001;429:79-91.

88. Martin-Schild S, Zadina JE, Gerall AA, Vigh S, Kastin AJ. Localization of endomorphin-2-like immunoreactivity in the rat medulla and spinal cord. Peptides 1997;18:1641-1649.

89. Zadina JE, Hackler L, Ge LJ, Kastin AJ. A potent and selective endogenous agonist for the mu-opiate receptor. Nature 1997;386:499-502.

90. Okada Y, Tsuda Y, Bryant SD, Lazarus LH. Endomorphins and related opioid peptides. Vitam Horm 2002;65:257-279.

91. Pérez-Mañá C, Papaseit E, Fonseca F, Farré A, Torrens M, Farré M. Drug interactions with new synthetic opioids. Front Pharmacol 2018; 9:1145.

92. Leite-Almeida H, Valle-Fernandes A, Almeida A. Brain projections from the medullary dorsal reticular nucleus: an anterograde and ret- 
rograde tracing study in the rat. Neuroscience 2006;140:577-595.

93. Ossipov MH, Dussor GO, Porreca F. Central modulation of pain. J Clin Investig 2010;120:3779-3787.

94. Fields HL, Malick A, Burstein R. Dorsal horn projection targets of ON and OFF cells in the rostral ventromedial medulla. J Neurophysiol 1995;74:1742-1759.

95. Moore RY, Bloom FE. Central catecholamine neuron systems: anatomy and physiology of the norepinephrine and epinephrine systems. Annu Rev Neurosci 1979;2:113-168.

96. Kirby LG, Freeman-Daniels E, Lemos JC, Nunan JD, Lamy C, Akanwa A, et al. Corticotropin-releasing factor increases GABA synaptic activity and induces inward current in 5-hydroxytryptamine dorsal raphe neurons. J Neurosci 2008;28:12927-12937.

97. Basbaum AI. Descending control of pain transmission: possible serotonergic-enkephalinergic interactions. Adv Exp Med Biol 1981;133: 177-189.

98. Loyd DR, Morgan MM, Murphy AZ. Morphine preferentially activates the periaqueductal gray-rostral ventromedial medullary pathway in the male rat: a potential mechanism for sex differences in antinociception. Neuroscience 2007;147:456-468.

99. Kirby LG, Rice KC, Valentino RJ. Effects of corticotropin-releasing factor on neuronal activity in the serotonergic dorsal raphe nucleus. Neuropsychopharmacology 2000;22:148-162.

100. Merrill RL. Central mechanisms of orofacial pain. Dent Clin North Am 2007;51:45-59, v.

101. Eippert F, Bingel U, Schoell ED, Yacubian J, Klinger R, Lorenz J, et al. Activation of the opioidergic descending pain control system underlies placebo analgesia. Neuron 2009;63:533-543.

102. Younger J, Mackey S. Fibromyalgia symptoms are reduced by lowdose naltrexone: a pilot study. Pain Med 2009;10:663-672.

103. Ueda M, Sugimoto K, Oyama T, Kuraishi Y, Satoh M. Opioidergic inhibition of capsaicin-evoked release of glutamate from rat spinal dorsal horn slices. Neuropharmacology 1995;34:303-308.

104. Scherrer G, Imamachi N, Cao YQ, Contet C, Mennicken F, O’Donnell $\mathrm{D}$, et al. Dissociation of the opioid receptor mechanisms that control mechanical and heat pain. Cell 2009;137:1148-1159.

105. Severino A, Chen W, Hakimian JK, Kieffer BL, Gaveriaux-Ruff C, Walwyn W, et al. Mu-opioid receptors in nociceptive afferents produce a sustained suppression of hyperalgesia in chronic pain. Pain 2018;159:1607-1620.

106. Rutten K, Schroder W, Christoph T, Koch T, Tzschentke TM. Selectivity profiling of NOP, MOP, DOP and KOP receptor antagonists in the rat spinal nerve ligation model of mononeuropathic pain. Eur J Pharmacol 2018;827:41-48.

107. Porreca F, Tang QB, Bian D, Riedl M, Elde R, Lai J. Spinal opioid mu receptor expression in lumbar spinal cord of rats following nerve injury. Brain Res 1998;795:197-203.

108. Thompson SJ, Pitcher MH, Stone LS, Tarum F, Niu G, Chen X, et al. Chronic neuropathic pain reduces opioid receptor availability with associated anhedonia in rat. Pain 2018;159:1856-1866.

109. Machelska H, Labuz D, Przewlocki R, Przewlocka B. Inhibition of nitric oxide synthase enhances antinociception mediated by mu, delta and kappa opioid receptors in acute and prolonged pain in the rat spinal cord. J Pharmacol Exp Ther 1997;282:977-984.

110. Neugebauer V, Galhardo V, Maione S, Mackey SC. Forebrain pain mechanisms. Brain Res Rev 2009;60:226-242.

111. Seminowicz DA, Moayedi M. The dorsolateral prefrontal cortex in acute and chronic pain. J Pain 2017;18:1027-1035.

112. Spivak B, Shohat B, Mester R, Avraham S, Gil-Ad I, Bleich A, et al. Elevated levels of serum interleukin-1 beta in combat-related posttraumatic stress disorder. Biol Psychiatry 1997;42:345-348.

113. Johnston IN, Milligan ED, Wieseler-Frank J, Frank MG, Zapata V, Campisi J, et al. A role for proinflammatory cytokines and fractalkine in analgesia, tolerance, and subsequent pain facilitation induced by chronic intrathecal morphine. J Neurosci 2004;24:7353-7365.

114. Raghavendra V, Rutkowski MD, DeLeo JA. The role of spinal neuroimmune activation in morphine tolerance/hyperalgesia in neuropathic and sham-operated rats. J Neurosci 2002;22:9980-9989.

115. Grabow TS, Dougherty PM. Cervicomedullary intrathecal injection of morphine produces antinociception in the orofacial formalin test in the rat. Anesthesiology 2001;95:1427-1434

116. Capuano A, De Corato A, Treglia M, Tringali G, Currò D, Dello Russo $\mathrm{C}$, et al. Peripheral antinociceptive effects of low doses of naloxone in an in vivo and in vitro model of trigeminal nociception. Neuropharmacology 2010;58:784-792.

117. Xu XJ, Hao JX, Seiger A, Hughes J, Hokfelt T, Wiesenfeld-Hallin Z. Chronic pain-related behaviors in spinally injured rats: evidence for functional alterations of the endogenous cholecystokinin and opioid systems. Pain 1994;56:271-277.

118. Roth RS, Geisser ME, Bates R. The relation of post-traumatic stress symptoms to depression and pain in patients with accident-related chronic pain. J Pain 2008;9:588-596.

119. Poundja J, Fikretoglu D, Brunet A. The co-occurrence of posttraumatic stress disorder symptoms and pain: is depression a mediator? J Trauma Stress 2006;19:747-751.

120. Sharp TJ, Harvey AG. Chronic pain and posttraumatic stress disorder: mutual maintenance? Clin Psychol Rev 2001;21:857-877.

121. Nazeri M, Razavinasab M, Abareghi F, Shabani M. Role of nitric oxide in altered nociception and memory following chronic stress. Physiol Behav 2014;129:214-220.

122. Afari N, Harder LH, Madra NJ, Heppner PS, Moeller-Bertram T, King C, et al. PTSD, combat injury, and headache in Veterans Returning from Iraq/Afghanistan. Headache 2009;49:1267-1276.

123. Smitherman TA, Kolivas ED. Trauma exposure versus posttraumatic stress disorder: relative associations with migraine. Headache 2013; 53:775-786

124. Alkan A, Guc ZG, Senler FC, Yavuzsen T, Onur H, Dogan M, et al. Breast cancer survivors suffer from persistent postmastectomy pain syndrome and posttraumatic stress disorder (ORTHUS study): a study of the palliative care working committee of the Turkish Oncology Group (TOG). Support Care Cancer 2016;24:3747-3755.

125. Coppens E, Van Wambeke P, Morlion B, Weltens N, Giao Ly H, Tack J, et al. Prevalence and impact of childhood adversities and post-traumatic stress disorder in women with fibromyalgia and chronic widespread pain. Eur J Pain 2017;21:1582-1590.

126. Gameiro GH, Andrade Ada S, de Castro M, Pereira LF, Tambeli CH, Veiga MC. The effects of restraint stress on nociceptive responses induced by formalin injected in rat's TMJ. Pharmacol Biochem Behav 2005;82:338-344.

127. Parikh D, Hamid A, Friedman TC, Nguyen K, Tseng A, Marquez P, et al. Stress-induced analgesia and endogenous opioid peptides: the importance of stress duration. Eur J Pharmacol 2011;650:563-567.

128. Zhang L, Li XX, Hu XZ. Post-traumatic stress disorder risk and brainderived neurotrophic factor Val66Met. World J Psychiatry 2016;6:1-6. 